\title{
CONCEPTUL DE MEDIU CONSTRUIT ACTIVATOR PENTRU PERSOANE VÂRSTNICE CU TULBURĂRI NEUROCOGNITIVE ÎNTR-O PERSPECTIVĂ INTERDISCIPLINARĂ/
}

THE CONCEPT OF DEMENTIA ENABLING BUILT ENVIRONMENT FROM AN INTERDISCIPLINARY PERSPECTIVE

Mihaela ZAMFIR (GRIGORESCU)*,

șef de lucrări. dr. arh./ lecturer PhD. arch.

Andreea Georgiana MARIN**, dr. psih. cl./PhD. cl. psych.

Ileana CIOBANU**, dr. C.S.III, biol./ PhD scient. researcher III, biol.

Dragoș-Cristian BOGDAN***, kinetoterapeut/physical therapist

Mihai-Viorel ZAMFIR****, asist. dr. med./assist. prof. PhD MD arch. mmg_architecturestudio@yahoo.com mihaela.zamfir@uauim.ro

andreea.budrica@gmail.com

ileanacuk@yahoo.co.uk

bogdandragoscristian@yahoo.com

mihai.zamfir@umfcd.ro

*Departamentul „Sinteza Proiectării de Arhitectură”, Facultatea de Arhitectură, Universitatea de Arhitectură şi Urbanism „Ion Mincu”, Bucureşti, RO/

"Synthesis of Architectural Design” Department, Faculty of Architecture, „Ion Mincu” University of Architecture and Urbanism, Bucharest, RO

**Clinica de Recuperare Medicală, Spitalul Universitar de urgență „Elias”, București, RO/

Medical Rehabilitation Clinic, „Elias” Emergency University Hospital, Bucharest, RO

***Secția „Kinetoterapie și motricitate specială”, Facultatea de Educație Fizică și Sport, Universitatea Spiru Haret, București, RO /"Physiotherapy and special motor skills" Department, Faculty of Physical Education and Sports, Spiru Haret University, Bucharest, RO

****Disciplina Fiziologie II-Neuroștiințe, Facultatea de Medicină, Universitatea de Medicină și Farmacie "Carol Davila", București, RO/

Physiology II and Neurosciences Division, Faculty of Medicine, „Carol Davila” University of Medicine and

Pharmacy, Bucharest, RO 


\section{Rezumat}

În contextul trendului ascendent de îmbătrânire a populației crește și numărul persoanelor afectate de tulburări neurocognitive (TNC), cea mai cunoscută fiind demența de tip Alzheimer. Menținerea pentru cât mai mult timp a unei calități cât mai bune a vieții la acești pacienți depinde foarte mult și de mediul construit, în acest sens vorbim despre medii construite activatoare.

Lucrarea are ca obiectiv explicitarea conceptului de mediu construit activator dedicat persoanelor vârstnice cu tulburări neurocognitive (MCAtn) cu aplicație pe centre rezidențiale pentru seniori de tip nursing-home și respiro.

Cercetarea de față investighează interdisciplinar conceptul MCAtn, interferând opiniile a cinci specialiști: arhitect, medic, psiholog, biolog și kinetoterapeut. Am analizat critic principiile MCAtn dintr-o perspectivă integrativă, pornind de la expertiza autorilor și folosind ca instrument judecata de valoare. Pentru a structura analiza asupra conceptului MCAtn am folosit setul de 10 principii formulate de Fleming et al în World Alzheimer Report 2020. În explicitarea celor 10 principii am utilizat metoda studiului de caz, analizând centre pentru seniori care oferă asistență de lungă durată.

Un mediu construit activator dedicat persoanelor vârstnice cu TNC se bazează pe o serie de principii: reducerea discretă a riscurilor, scară redusă (cămine / centre de zi), facilitarea accesului vizual, managementul nivelelor de stimulare, încurajarea exercițiului fizic și a implicării în activități, menținerea / crearea unui spațiu familiar,

\section{Abstract}

In the context of the upward trend of population aging, the number of people affected by neurocognitive disorders (NCD) is also increasing, the most well-known being Alzheimer's dementia. Maintaining for as long as possible a better quality of life in these patients depends very much on the built environment, in this sense we are talking about enabling built environments.

The paper aims to explain the concept of enabling built environment dedicated to the older persons with neurocognitive disorders (EBEnc) with application on residential centers for seniors such as nursing-home and respite centers.

The present research interdisciplinary investigates the concept of EBEnc, interfering with the opinions of five specialists: architect, physician, psychologist, biologist and physical therapist. We critically analyzed the EBEnc principles from an integrative perspective, starting from the authors' expertise and using value judgment as a tool. To structure the analysis on the EBEnc concept we used the set of 10 principles formulated by Fleming et al in World Alzheimer Report 2020. In explaining the 10 principles we used the case study method, analyzing elderly centers that provide long-term care.

An activating built environment dedicated to the elderly with NCD is based on a number of principles: discreet risk reduction, small scale (homes / day centers), facilitating visual access, management of stimulation levels, encouraging exercise and involvement in activities, maintaining / creating a familiar space, outlining spatial hypostases for 
conturarea unor ipostaze spațiale pentru interacțiune / retragere (acasă / cămin / comunitate) și nu în ultimul rând, design în concordanță cu viziunea asupra vieții.

Conturarea MCAtn este rezultatul unei munci de echipă, interdisciplinare. Un design pe principii dementia-friendly este un cumul atent gestionat care creează un echilibru optim de stimulare a persoanei vârstnice cu TNC. Un spaţiu activator pentru o persoană vârstnică cu TNC oferă o stimulare multisenzorială. MCAtn va contribui la menținerea indepedenței pentru cât mai mult timp a persoanelor cu TNC. interaction / retreat (home / nursing-home / community) and last but not least, design in accordance with the vision of life.

The shaping of EBEnc is the result of an interdisciplinary teamwork. A dementia-friendly design is a carefully managed combination that creates an optimal balance of stimulation of the older person with NCD. An activating space for an elderly person with NCD provides multisensory stimulation. EBEnc will help maintain the independence of people with NCD for as long as possible.

\section{Cuvinte cheie/ Keywords}

dementia-friendly, mediu construit activator, arhitectură, calitatea vieții, interdisciplinaritate/ dementia-friendly, enabling built environment, architecture, quality of life, interidsciplinarity

\section{Introducere}

La nivel global asistăm la o accelerare a procesului de îmbătrânire a populației cu accentuări semnificative la nivel european, o provocare pentru arhitectură și urbanism. În concordanță cu datele furnizate de ONU, procentul de persoane vârstnice (65+) va crește de la 9\% (2019) la 16\% (2050) (UN, 2019, World Population Prospects: the 2019 Revision). Organizația Mondială a Sănătății (WHO) estimează că între 2015 și 2050 procentul din populație pentru adulții 60+ va deveni aproape dublu, de la 12\% la 22\% (WHO, 2018). În 2018, pentru prima dată în istorie, la nivel global, persoanele 65+ au depășit copiii cu vârstă $<5$ ani (UN, Ageing). La nivel european, trendul de îmbătrânire a populației este chiar mai pronunțat, se

\section{Introduction}

On global level we assist to an acceleration of the aging process of the population, with significant emphasis at European level, a challenge for architecture and urbanism. According to UN provided data, the average of elderly persons (65+) will increase from 9\% (2019) to 16\% (2050). (UN, 2019, World Population Prospects: the 2019 Revision). World Health Organisation (WHO) estimates that between 2015 and 2050 the percentage of the population for adults $60+$ will become almost double, from $12 \%$ to $22 \%$ (WHO, 2018). In 2018, for the first time in our history, at global level, the persons over 65 years exceeded the children under 5 years old. (UN, Ageing) At European level, the aging trend of the population is even more 
estimează ca până în 2050 un procent de $28 \%$ din populație să aibă 65+ (UN, 2019, World Population Prospects: the 2019 Revision). Trend-ul de îmbătrânire a populației este dublat de o tendință accentuată de urbanizare (Comisia Europeană, n.d., accesat în 16.10.2020; WHO, 2007), se estimează că în 2030 Europa va ocupa al doilea loc la nivel mondial cu un procent de aproape $80 \%$ populație urbană (WHO, 2007). Peste aceste tendințe, pandemia cu COVID-19 pe care o experimentăm se suprapune putând influența evoluția demografică și aducând noi provocări (UN, 2020, COVID-19 and Older Persons: A Defining Moment for an Informed, Inclusive and Targeted Response).

În contextul îmbătrânirii populației crește și numărul persoanelor cu tulburări neurocognitive (termen denumit mai departe în text TNC). Dintre tulburările neurocognitive, cea mai frecventă este demența de tip Alzheimer, urmată de demența de cauză vasculară și alte tipuri de demențe (cu corpi Lewy, fronto-temporală, Parkinson, alte forme mai rare de demență). Se estimează că până în 2050 aproape 132 milioane de persoane vârstnice vor trăi cu demență (Chan et al, 2019).

Simptomele demențelor care pot fi corelate cu mediul sunt: dezorientare spațială, dizabilitate locomotorie, tulburări de dispoziție, tulburări de percepție. Acestea pot fi cauzate de zgomote sau imagini complexe care conțin culori și texturi care pot interfera greșit pe o hartă mentală alterată, efectul fiind că mulți vârstnici cu TNC pot auzi zgomote sau vedea obiecte sau imagini care în realitate nu există (Trivedi, 2019; Oliveira, 2015).

Majoritatea vârstnicilor vor să îmbătrânească în propriul cămin, în comunitatea în care au trăit pronounced, it is estimated that by 2050 a percentage of $28 \%$ of the population will be $65+$. (UN, 2019, World Population Prospects: the 2019 Revision). The aging trend of the population is doubled by an accentuated tendency of urbanization (European Commission, n.d., accessed in 16.10.2020; WHO, 2007), it is estimated that by 2030 Europe will take the second place in the world with a percentage of almost $80 \%$ urban population (WHO, 2007). Over these trends, the pandemic with COVID-19 that we are experiencing overlaps, being able to influence demographic evolution and bring new challenges. (UN, 2020, COVID-19 and Older Persons: A Defining Moment for an Informed, Inclusive and Targeted Response).

In the context of an aging population the number of people with neurocognitive disorders (term referred in the text later on with NCD) is also increasing. From all the neurocognitive disorders, the most common is Alzheimer Dementia, followed by Vascular Dementia and other types of dementia (with Lewy bodies, fronto-temporal, Parkinson's, other rarer forms of dementia). It is estimated that by 2050 almost 132 million elderly people will live with dementia (Chan et al, 2019).

Symptoms of dementia that can be correlated with the environment are: spatial disorientation, locomotor disability, mood disorders, perception disorders. These can be caused by complex noises or images that contain colors and textures that can be misinterpreted, an altered mind map, so, due to these symptoms, many NCD seniors may hear noises or see objects or images that do not actually exist. (Trivedi, 2019; Oliveira, 2015).

Most of the elderly people want to grow old in their own home, in the community where they have lived 
întreaga viață (National Institute on Aging (n.d.)) dar când vorbim despre vârstnicul cu multiple comorbidități și în special cu tulburări neurocognitive (TNC), instituționalizarea poate $\mathrm{fi}$ singura opțiune. Arhitectura trebuie să incumbe perspectiva vârstei în arhitectură şi să găsească cele mai potrivite răspunsuri (Zamfir M, 2020). Echipa noastră promovează de 10 ani în cadrul evenimentelor la care participă importanța includerii perspectivei vârstei în arhitectură ${ }^{1}$ și de peste 5 ani a introducerii în proiectarea de arhitectură a acestei categorii de utilizatori, vârstnicii cu tulburări neurocognitive/demență, care devine din nefericire din ce în ce mai mare.

Primele preocupări de cercetare asupra modului în care mediul construit poate sprijini asistența vârstnicilor cu demență, poate contribui la starea de bine a acestora și la creșterea calității vieții au apărut în anii '80 (Lawton MP, 1984; Calkins MP, 1988; Hyde J, 1989). În anii '90 apar alte nume de referință în acest sens (Schiff MR,1990; Cohen \& Weisman, 1991; Brawley EC,1997; Jud, Marshall \& Phippen, 1998). În anii 2000, odată cu accelerarea procesului de îmbătrânire a populației și implicit creșterea incidenței tulburărilor neurocognitive, preocupările devin mai intense și diversificate, observându-se o creștere a numărului de publicații pe subiectul design-ului și arhitecturii dementia-friendly (Fleming R, 2020). Toți acești autori au căutat să formuleze principii de design dementia-friendly care variază ca număr între 8 și 12 elemente. Cea mai recentă lucrare de referință în acest sens este World Alzheimer Report 2020 care listează 10 principii de design pentru un mediu construit activator dementia-friendly. Un astfel de mediu trebuie să fie centrat pe utilizator și pe abilitățile acestuia, trebuie their whole life (National Institute on Aging (n.d.)) but when we are speaking about an older person with multiple comorbidities and especially those diagnosed with neurocognitive disorders (NCD), institutionalisation may be the only available option. Architecture must be responsible for the age perspective in architecture and find the most appropriate answers. (Zamfir M, 2020; Zamfir MV, 2011). Our team has been promoting for 10 years in scientific events involving the importance of including the perspective of age in architecture ${ }^{1}$ and for over 5 years the introduction in the architectural design of this category of users, the elderly with neurocognitive disorders / dementia, which unfortunately becomes more and bigger.

The first research concerns on how the built environment can support the care of the elderly with dementia, can contribute to their well-being and increase the quality of life appeared in the '80s. (Lawton MP, 1984; Calkins MP, 1988; Hyde J, 1989). Other reference names in this regard appeared in the '90s. (Schiff MR,1990; Cohen \& Weisman, 1991; Brawley EC,1997; Jud, Marshall \& Phippen, 1998). In the 2000s, once with the aging process acceleration and so the increase in the incidence of neurocognitive disorders, concerns become more intense and diversified, with an increase in the number of publications on the subject of dementiafriendly design and architecture. (Fleming R, 2020). All these authors sought to formulate dementiafriendly design principles that range in number from 8 to 12 elements. The most recent reference work in this regard is the World Alzheimer's Report 2020 which lists 10 design principles for a dementiafriendly enabling built environment. Such an environment must be focused on the user and his abilities, it must be significant / with meanings, 
să fie semnificativ / cu semnificații, plăcut, relaxant, sigur, accesibil, familiar, interactiv și în același timp liniștit (Fleming R, 2020).

Analiza conceptului de mediu construit activator dementia-friendly din diferite perspective este esențială întrucât contribuie la creșterea cunoașterii în domeniu și ajută la dezvoltarea de cadre conceptuale pentru cercetare.

\section{Obiectiv}

Lucrarea are ca obiectiv explicitarea conceptului de mediu construit activator dedicat persoanelor vârstnice cu tulburări neurocognitive (MCAtn) cu aplicație pe centre rezidențiale pentru seniori de tip nursing-home și respiro.

\section{Materiale și metode}

Cercetarea de față analizează interdisciplinar conceptul de Mediu Construit Activator dedicat persoanelor vârstnice cu tulburări neurocognitive (MCAtn), interferând opiniile a cinci specialiști: arhitect, medic, psiholog, biolog și kinetoterapeut. Am analizat critic principiile MCAtn dintr-o perspectivă integrativă, pornind de la expertiza autorilor și folosind ca instrument judecata de valoare. Pentru a structura analiza asupra conceptului de MCAtn am folosit setul de 10 principii formulate de Fleming et al. în World Alzheimer Report 2020 - un document actual cu abordare integrativă, de referință în domeniul conceptului de MCAtn. Lucrarea de față explicitează cele 10 principii într-o formulă interdisciplinară sub coordonarea unui arhitect.

În explicitarea celor 10 principii am folosit metoda studiului de caz, analizând centre pentru seniori care pleasant, relaxing, safe, accessible, familiar, interactive and at the same time quiet. (Fleming R, 2020).

The analysis of the concept of a dementia-friendly enabling built environment from different perspectives is essential as it contributes to the increase of knowledge in the field and helps to develop conceptual frameworks for research.

\section{Objective}

This paper aims to explain the concept of enabling built environment dedicated to the older persons with neurocognitive disorders (EBEnc) with application on nursing-homes and respite centers.

\section{Materials and Methods}

The present research is an interdisciplinary analyzis of the concept of Enabling Built Environment dedicated to the elderly with neurocognitive disorders (EBEnc), interfering with the opinions of five specialists: architect, physician, psychologist, biologist and physical therapist. We critically analyzed the EBEnc principles from an integrative perspective, starting from the authors' expertise and using value judgment as a tool. To structure the analysis on the concept of EBEnc we used the set of 10 principles formulated by Fleming et al. in World Alzheimer Report 2020 - a current document with an integrative approach, a reference in the field of the concept of EBEnc. This paper explains the 10 principles in an interdisciplinary manner under the coordination of an architect.

In explaining the 10 principles we used the case report method, analyzing centers for seniors that 
oferă asistență de lungă durată. În studiul acestor centre am evaluat modul în care sunt implementate cele 10 principii, accentuând caracteristicile arhitecturale: aspect exterior-interior, functionalitate, gabarite, accesibilitate, sustenabilitate, amplasarea în cadrul comunității. Pentru studiile de caz am folosit exemple de centre pentru seniori din Europa, precum și un exemplu de spațiu de stimulare multisenzorială și reamintire (proiectul Sense Garden²).

\section{Rezultate}

World Alzheimer Report (2020) în peste 500 de pagini discută amănunțit aspectele legate de design, demnitate și demență. Alzheimer Disease International listează în promovarea congresului care va avea loc acest în acest an (2020) în decembrie (Alzheimer's Disease International. (n.d.)) 8 recomandări făcute de Fleming et ali ${ }^{3}$ care evidențiază importanța acordată mediului construit, designului și arhitecturii în creșterea calității vieții persoanelor vârstnice cu demență/tulburări neurocognitive (TNC). Se recomandă includerea designului pentru persoanele cu tulburări neurocognitive în curricula școlilor de arhitectură și design, un aspect important în formarea arhitecților viitorului. Alte recomandări făcute de Fleming et ali, care accentuează importanța calității mediului construit pentru persoanele cu demență, sunt: realizarea unui set comun de principii de design și includerea acestora în Planurile Naționale Pentru Demență; adoptarea unor ghiduri de design dementia-friendly și promovarea acestora; încurajarea economiștilor care activează în domeniul sănătății publice să colaboreze cu designerii pentru a găsi raportul optim dintre provide long-term care. In the study of these centers we evaluated the way in which the 10 principles are implemented, emphasizing the architectural characteristics: outdoor-indoor aspect, functionality, dimensions, accessibility, sustainability, location within the community. For the case reports we used examples of centers for seniors in Europe, as well as an example of space for multisensory stimulation and reminiscence (the Sense Garden project ${ }^{2}$ ).

\section{Results}

The World Alzheimer's Report (2020) in over 500 pages discusses in detail the aspects related to design, dignity and dementia. Alzheimer Disease International lists in the promotion of the congress that will take place this year (2020) in December (Alzheimer's Disease International. (n.d.)) 8 recommendations made by Fleming et ali $^{3}$ highlighting the importance given to the built environment, design and architecture in increasing the quality of life of elderly people with dementia / neurocognitive disorders (NCD). It is recommended to include design for people with neurocognitive disorders in the curriculum of architecture and design schools, an important aspect in the training of architects of the future. Other recommendations made by Fleming et ali, which emphasize the importance of the quality of the built environment for people with dementia, are: the development of a common set of design principles and their inclusion in the National Dementia Plans; adopting dementia-friendly design guides and promoting them; encouraging public health economists to work with designers to find the best balance between the costs and benefits of staying in the community for 
costurile și beneficiile rămânerii în comunitate a vârstnicilor cu tulburări neuro-cognitive; încurajarea guvernelor de a fi proactive în angrenarea arhitecților, operatorilor și tuturor părților interesate în designul dedicat persoanelor vârstnice cu tulburări neurocognitive (Fleming, 2020).

\section{Principii de design pentru medii activatoare dedicate persoanelor vârstnice cu tulburări neurocognitive (Fleming \& Bennet, 2020)}

\section{Reducerea discretă a riscurilor}

Mediu controlat: Se recomandă promovarea unui mediu ușor de interpretat, liniștit, acordând atenție reducerii zgomotelor de fond și disturbărilor vizuale. Căile de circulație se recomandă a fi proiectate cât mai optim (Silverstein, 2006) astfel încât să fie evitate dezorientarea, reducerea agitației și dromomaniei $^{4}$ (Adekoya, 2019) precum și riscul de cădere. În acest sens, ușile de la camerele rezidenților pot fi în culori diferite (Níall McLaughlin Architects, n.d. a) astfel încât să fie ușor de reperat (reamintim faptul că persoanele cu tulburări neurocognitive își amintesc mai curând o culoare decât funcțiunea unui spațiu). Pe zonele de circulații este esențial să fie montate bare de susținere (cu dublă mână curentă $h=90 \mathrm{~cm}$ pentru persoanele independente și $\mathrm{h}=60-75 \mathrm{~cm}$ pentru utilizatorii de scaun rulant), să fie amenajate zone de odihnă (Elderly Accommodation Counsel, 2020). Un alt aspect important este iluminatul care trebuie să fie controlat, atât cel natural cât și cel artificial pentru evitarea strălucirilor (Níall McLaughlin Architects, the elderly with neuro-cognitive impairments; encouraging governments to be proactive in engaging architects, operators and all stakeholders in the design of older people with neurocognitive disorders (Fleming, 2020).

\section{Design principles for enabling built environ- ments dedicated to older persons with neuro-cognitive disorders (Fleming \& Bennet, 2020)}

\section{Unobtrusively reduse risks}

Controlled environment: It is recommended to promote an easy to interpret, quiet environment, paying attention to the reduction of background noise and visual disturbances. Traffic routes are recommended to be designed as optimally as possible (Silverstein, 2006) so as to avoid disorientation, reduce agitation and wandering ${ }^{4}$ (Adekoya, 2019) as well as the risk of falling. In this sense, the doors of the residents' rooms can be in different colors (Níall McLaughlin Architects, n.d. a) so that they are easy to spot (remember that people with neurocognitive disorders remember a color rather than the function of a space). On the traffic areas it is essential to mount grab bars (with double current hand $h=90 \mathrm{~cm}$ for independent people and $\mathrm{h}=60-75 \mathrm{~cm}$ for wheelchair users), to design rest areas (Elderly Accommodation Counsel, 2020). Another important aspect is the lighting that must be controlled, both natural and artificial to avoid glare (Níall McLaughlin Architects, n.d. b). The sound must also be controlled to avoid the risk of agitation 
n.d. b). Sunetul de asemenea trebuie să fie controlat pentru a evita riscul de agitație și implicit, riscul de cădere (Níall McLaughlin Architects, n.d. c).

Siguranță fără bariere: În scopul evitării unor bariere ale mediului pentru siguranța utilizatorului, o arhitectură pe principii dementia-friendly presupune de asemenea și includerea Tehnologiei Asistive (TA), Ambient Assistive Living (AAL) și telemedicinei (Telecare, Telehealth). (AAB DIE RAUMKULTUR $\mathrm{GMBH}$, n.d.; AIPRemodeling.com, n.d.).

Spații exterioare accesibile și sigure: Persoanele vârstnice trebuie încurajate să petreacă cât mai mult timp în aer liber mai ales atunci când vorbim despre persoane instituționalizate. Petrecerea timpului în aer liber, la soare, practicarea de exerciții fizice în natura, implicarea în activități precum grădinăritul trebuie susținute de spații exterioare optim amenajate pentru persoane cu tulburări neurocognitive. Se recomandă amenajarea de spații exterioare accesibile, perceptibile din interior, în acest sens pot $\mathrm{fi}$ realizate suprafețe vitrate generoase (studiolada, n.d.; Ott, n.d. a; Ocaña, n.d. a). Spațiile exterioare (ex. curți interioare) ar trebui să evite denivelările iar dacă acestea există trebuiesc preluate cu rampe cu pante corespunzătoare pentru un utilizator de scaun rulant (maxim 15\% pentru denivelări $<20 \mathrm{~cm}$ și maxim $8 \% /$ recomandat $5 \%$ pentru denivelări $>20 \mathrm{~cm}$ ) (modlar.com, n.d). Sunt recomandate pavajele antiderapante cu aspect mat, marcarea clară a zonelor de circulație printr-o delimitare cromatică și/sau de textură (McManus, 2020.08.24). Recomandarea ar fi ca spațiile exterioare să fie amenajate ca grădini terapeutice care utilizează principii precum: circulația în buclă, stimulare multisenzorială, zone de activități diferite și bine marcate (Sym Studio, n.d.). and, implicitly, the risk of falling (Níall McLaughlin Architects, n.d. c).

Safety without obstructions: In order to avoid environmental barriers for user safety, a dementiafriendly architecture also involves the inclusion of Assistive Technology (AT), Ambient Assistive Living (AAL) and telemedicine (Telecare, Telehealth) (AAB DIE RAUMKULTUR GMBH, n.d.; AIPRemodeling.com, n.d.).

Accessible and safe outdoor spaces: Older people should be encouraged to spend as much time outdoors as possible, especially when it comes to institutionalized people. Spending time outdoors, in the sun, exercising in nature, engaging in activities such as gardening must be supported by outdoor spaces optimally designed for people with neurocognitive disorders. It is recommended to arrange accessible outdoor spaces, perceptible from the inside, in this sense generous glazed surfaces can be made (studiolada, n.d; Ott, n.d. a; Ocaña, n.d. a). Outdoor spaces (eg inner courtyards) should avoid unevenness and if they exist they should be taken up with ramps with appropriate slopes for a wheelchair user (maximum 15\% for unevenness $<20 \mathrm{~cm}$ and maximum $8 \%$ / recommended $5 \%$ for denivelation> $20 \mathrm{~cm}$ ). Non-slip pavements with a matte appearance, clear marking of traffic areas through a chromatic and / or texture delimitation are recommended (McManus, 2020.08.24). The recommendation would be for outdoor spaces to be designed as therapeutic gardens that use principles such as: looping, multisensory stimulation, different and well-marked areas of activity (Sym Studio, n.d.). 


\section{Scară arhitecturală redusă}

Scara spațiului, a clădirii dar și a elementelor de design poate afecta comportamentul și dispoziția persoanelor cu tulburări neurocognitive. Atunci când vorbim despre vârstnici instituționalizați se recomandă un număr de rezidenți redus pentru a evita suprastimularea și agitația, drept urmare o scară redusă a clădirii/ansamblului. Se recomandă dezvoltarea acestor centre dacă este posibil doar pe parter, de cele mai multe ori condițiile nu permit acest lucru și se merge pe un regim de înălțime parter+1 etaj, parter+2 etaje.

Căminul Santa Rita (2003, Spania) se dezvoltă integral pe parter fiind organizat în jurul unei curți interioare cu formă meandrică, pe principiile designului terapeutic. Camerele rezidenților se deschid direct spre această grădină, fiind în acest fel încurajată activitatea în aer liber (Ocaña, n.d. b). Desi scara centrului este redusă, confortul oferit rezidenților este maxim, camerele de tip single sunt majoritare (S utilă cameră $19 \mathrm{mp}$ ) dar sunt și camere de tip double (S utilă cameră 26mp) (Ocaña, n.d. c). Un alt exemplu este Căminul Hainburg (2009, Austria) care a primit o extindere nouă organizată într-o bară dublu tract cu schemă funcțională clară, pe o înălțime $p+1,26$ de camere single (S utilă cameră $21 \mathrm{mp}$ ) pe nivel (Ott, n.d. b; archdaily.com, n.d.).

Se recomandă astfel în cazul căminelor pentru vârstnici ca circulațiile să fie bine iluminate, posibil de a se deschide direct spre spațiul exterior printr-o suprafață vitrată generoasă care să permită vizualizarea acestuia [de ex. Căminul Hodos, Slovenia, 2010, (Kambič, n.d.)]. Dacă vorbim despre

\section{Provide a human scale}

The scale of the space, of the building but also the design elements can affect the behavior and mood of people with neurocognitive disorders. When talking about institutionalized elderly, it is recommended a small number of residents to avoid overstimulation and agitation, as a result of a small scale of the building / ensemble. It is recommended to develop these centers if possible only on the ground floor, most of the time the conditions do not allow this and go on a height regime $\mathrm{GF}+1, \mathrm{GF}+2$.

Santa Rita Home (2003, Spain) is fully developed on the ground floor, being organized around a meandering courtyard, based on the principles of therapeutic design. The residents' rooms open directly to this garden, thus encouraging outdoor activity (Ocaña, n.d. b). Although the scale of the center is small, the comfort offered to the residents is maximum, the single type rooms are majority ( $A$ room $\sim 19 \mathrm{sqm}$ ) but there are also double type rooms (A room $\sim 26 s q m$ ) (Ocaña, n.d. c).

Another example is the Hainburg Nursing Home (2009, Austria) which received a new extension organized in a double tract bar with a clear functional scheme, on a height GF+1, 26 single rooms ( $A^{\sim}$ 21sqm) per level (Ott, n.d. b; archdaily.com, n.d.).

It is thus recommended in the case of homes for the elderly that the circulations be well lit, possible to open directly to the outside space through a generous glazed surface that allows its visualization [de ex. Căminul Hodos, Slovenia, 2010, (Kambič, n.d.)]. If we are talking about an older person living 
o persoană în vârstă care locuiește acasă, într-un apartament este important ca accesul vizual să fie nemijlocit asupra tuturor încăperilor încă de la intrare, mobila să fie astfel poziționată încât să ajute la reperarea funcțiunii spațiului respectiv, prin ușa deschisă. Baia ar trebuie să fie în relație directă cu dormitorul, mai mult de atât, pe cât este posibil se recomandă ca din pat, prin ușa deschisă a băii să poate fi reperat vizual vasul de WC. Se recomandă facilitarea accesului vizual în exterior și, atunci când există terase, balcoane, acces vizual direct, din pat, canapea sau fotoliu spre ușa spre acestea.

\section{Facilitarea accesului vizual}

Un mediu ușor de înțeles poate fi o resursă importantă în menținerea unui stil de viață activ și pe cât posibil independent atunci când vorbim de persoane TNC. Este important pentru persoanele care trăiesc cu demență să poată recunoaște unde sunt, de unde vin și încotro se îndreaptă. În acest sens arhitectul poate lucra cu ancore vizuale (Marquardt, 2011), puncte cheie în proiectarea/amenajarea locuințelor, instituțiilor de asistență. Se recomandă realizarea unei scheme funcționale clare care să fie păstrată pe cât posibil nemodificată, să existe acces vizual imediat și cât mai direct spre zone importante care în cazul unei locuințe sunt livingul, locul de luat masa, dormitorul, baia, bucătăria și spațiile exterioare.

Conform Fleming R (2020), "un acces vizual bun deschide oportunități pentru a fi activ și dă persoanelor care trăiesc cu demență încrederea de a-și explora mediul". at home, in an apartment it is important that the visual access is direct on all rooms from the entrance, the furniture is positioned so as to help spot the function of the space through the open door. The bathroom should be in direct contact with the bedroom, moreover, as far as possible it is recommended that from the bed, through the open door of the bathroom can be visually spotted the toilet bowl. It is recommended to facilitate visual access to the outside and, when there are terraces, balconies, direct visual access from the bed, sofa or armchair to the door to them.

\section{Allow people to see and be seen}

An easy-to-understand environment can be an important resource in maintaining an active and independent lifestyle as much as possible when it comes to people with NCD. It is important for people living with dementia to be able to recognize where they are, where they come from and where they are going. In this sense, the architect can work with visual anchors (Marquardt, 2011), key points in the design / arrangement of housing, assistance institutions. It is recommended to create a clear functional scheme that is kept as unchanged as possible, to have immediate and direct visual access to important areas that in the case of a home are the living room, dining room, bedroom, bathroom, kitchen and outdoor spaces.

According to Fleming R (2020), "good visual access opens up opportunities for engagement and gives the persons living with dementia the confidence to explore their environment." 


\section{Reducerea stimulării care nu ajută}

Un aspect important este managementul nivelelor de stimulare întrucât percepţia alterată şi capacitatea redusă de procesare a informaţiilor în timp real poate induce, în caz de suprastimulare, iluzii vizuale, comportament agresiv, noncomplianţa la îngrijire, confuzie nocturnă/sundowning (Bridges, 2020). Stimulii negativi trebuie reduși, aici intră deopotrivă atât cei vizuali cât și cei auditivi. Trebuie acordată atenție unui balans optim între spațiile care stimulează și cele care induc o stare de liniște. Se recomandă eliminarea luminii puternice, a reflexiilor și strălucirii, evitarea imprimeurilor geometrice sau a altor grafisme de contrast mare, evitarea zgomotelor care pot induce stres și realizarea unor "camere liniștite" / quiet rooms în care vârstnicul se poate retrage în scopul prevenirii/diminuării agitației (Níall McLaughlin Architects, n.d. c).

\section{Optimizarea stimulilor care ajută}

Dacă efectele suprastimulării sunt dovedite ca fiind negative, în același timp stimularea pe paliere decelate corect poate activa persoana vârstnică afectată de demență. Astfel, vârstnicul are nevoie de un nivel de iluminat de 3 ori mai mare decât un adult tânăr (Kunduraci, 2017) pentru a-și păstra un stil de viață activ, se recomandă suprafețe vitrate generoase cu elemente de control al însoririi reglabile care să permită controlul strălucirii. În locul de luat masa se recomandă utilizarea nuanțelor de roșu sau portocaliu care stimulează pofta de mâncare (Kane \& Karatzas, n.d.).

\section{Reduce unhelpful stimulation}

An important aspect is the management of stimulation levels as altered perception and reduced ability to process information in real time can induce, in case of overstimulation, visual illusions, aggressive behavior, non-compliance with care, night confusion / sundowning (Bridges, 2020). Negative stimuli must be reduced, including both visual and auditory stimuli. Attention must be paid to an optimal balance between spaces that stimulate and those that induce a state of tranquility. It is recommended to eliminate strong light, reflections and brightness, avoid geometric prints or other high contrast graphics, avoid noise that can induce stress and create "quiet rooms" in which the elderly can retire in order to prevent / reduce agitation (Níall McLaughlin Architects, n.d. c).

\section{Optimise helpful stimulation}

If the effects of overstimulation are proven to be negative, at the same time stimulation on correctly detected levels can activate the elderly person affected by dementia. Thus, the elderly need a level of lighting 3 times higher than a young adult (Kunduraci, 2017) to maintain an active lifestyle, it is recommended generous glazed surfaces with adjustable sun control elements that allow brightness control. In the dining, it is recommended to use tones of red or orange that stimulate the appetite (Kane \& Karatzas, n.d.). 


\section{6. Încurajarea exercițiului fizic și a implicării în activități}

Activitatea fizică este o componentă semnificativă pentru un stil de viață sănătos care crește speranța de viață, previne sarcopenia și sindromul de fragilitate la vârstnic. Menținerea unui stil de viață activ în concordanță cu stadialitatea patologiei de tipul bolii Alzheimer este un obiectiv important pentru menținerea stării de bine și a unei calități a vieții cât mai bune. Studiile au dovedit că exercițiile moderate de 2 ori/ săptămână încetinesc cu aproximativ 30\% deteriorarea progresivă în abilitatea de a performa activități zilnice (Hallie, 2020).

Un program de forță/strength training de 12 săptămâni la persoane $90+$, rezidenți în cămine a dublat rezistența piciorului (Fiatarone, 1990). La vârstnici 75+ s-au recuperat 20 de ani de forță / rezistență pierdută printr-un program de 12 săptămâni de exerciții de forță pe scaun (Skelton, 2018). Un program de 12 săptămâni de exerciții funcționale de înaltă intensitate la vârstnici cu demență instituționalizați a îmbunătățit forța, echilibrul și ADLs (Toots, 2016).

Pentru pacienții cu forme ușoare sau medii de demență se recomandă grădinăritul, jocuri cu mingea la interior, dans, exerciții stând pe scaun, înot, Tai Chi/Qiqong, plimbări (Alzheimer's Society. 2020). În acest sens, arhitectura (Day, 2000) trebuie să utilizeze principiile Designului Universal (echitabilitate, flexibilitate, simplu şi intuitiv, informație perceptibilă, efort fizic scăzut, dimensionare şi spațiu) (Preiser, 2001). Este important ca în cadrul centrelor dedicate

\section{Support movement and engagement}

Physical activity is a significant component of a healthy lifestyle that increases life expectancy, prevents sarcopenia and frailty syndrome in the elderly. Maintaining an active lifestyle in accordance with the stage of Alzheimer's disease pathology is an important goal for maintaining well-being and a better quality of life. Studies have shown that moderate exercise twice a week slows by about 30\% the progressive deterioration in the ability to perform daily activities (Hallie, 2020).

A 12 weeks strength training program for 90+ residents in nursing-homes doubled leg strength (Fiatarone, 1990). At 75+ seniors, 20 years of lost strength / endurance were recovered through a 12 weeks program of chair strength exercises (Skelton, 2018). A 12 weeks program of high-intensity functional exercise in institutionalized elderly people with dementia improved strength, balance, and ADLs (Toots, 2016).

For patients with mild or moderate forms of dementia, gardening, indoor ball games, dancing, sitting exercises on the chair, swimming, Tai Chi / Qiqong, walking (Alzheimer's Society. 2020) are recommended. In this sense, architecture (Day, 2000) must use the principles of Universal Design (equitable use, flexibility, simple \& intuitive, perceptible information, low physical effort, sizing \& space) (Preiser, 2001). It is important that in the centers dedicated to the elderly with neurocognitive 
persoanelor vârstnice cu tulburări neurocognitive să există o sală în care se pot face exerciții fizice și kinetoterapie.

Pentru un spațiu dedicat activității fizice se recomandă un design simplu și funcțional, facilitarea unei conexiuni directe între utilizator și natură care are ca efect catalizarea funcționalității persoanei vârstnice. Un astfel de spațiu ar trebui să ofere oportunitatea combinării antrenamentului cognitiv și al abilităților sociale cu antrenamentul fizic. Spațiul trebuie să ofere siguranță și confort, atenție la oglinzi, sunt recomandate a se folosi cu moderație în sălile de sport dedicate vârstnicilor cu demență (Patterson, n.d.). Culorile care activează sunt din spectrul cald, galben-roșu.

\section{Crearea unui spațiu familiar}

Simpla reamenajare a locuinței unei persoane vârstnice în concordanță cu nevoile noi de utilizare care apar atunci când este o suferință precum boala Alzheimer sau un pas mai radical, instituționalizarea, produce un stres important. Persoana vârstnică are nevoie de un confort emoțional, de un design care să îi fie familiar, în concordanță cu așteptările acestuia de utilizare. Propunem spre analiză 2 camere din 2 centre de tip cămin, Căminul Graz [2014, Austria (Dietger Wissonig Architekten, n.d.)] și Căminul Alcacer do Sal [2010, Portugalia (Fernando Guerra | FG + SG, n.d.)], 2 atitudini diferite. În primul exemplu se observă un design domestic, culori calde, materiale naturale precum lemn, mobilier cu tendinte clasice. Al doilea exemplu oferă un spațiu complet alb care deși are calități arhitecturale incontestabile nu este în concordantă cu nevoile unui utilizator vârstnic cu tulburări disorders to be a space where physical exercises and physical therapy can be done.

For a space dedicated to physical activity, a simple and functional design is recommended, facilitating a direct connection between the user and nature, which has the effect of catalyzing the functionality of the elderly person. Such a space should provide an opportunity to combine cognitive training and social skills with physical training. The space must provide safety and comfort, attention to mirrors, are recommended to be used sparingly in gyms dedicated to the elderly with dementia (Patterson, n.d.). The activating colors are from the warm, yellow-red spectrum.

\section{Create a familiar space}

The simple redevelopment of an older person's home in accordance with the new needs of use that arise when there is a suffering such as Alzheimer's disease or a more radical step, institutionalization, produces significant stress. The older person needs emotional comfort, a design that is familiar to him, in accordance with his expectations of use. We propose for analysis 2 rooms from 2 nursing-homes, Graz Home [2014, Austria (Dietger Wissonig Architekten, n.d.)] and Alcacer do Sal Home [2010, Portugalia (Fernando Guerra | FG + SG, n.d.)], 2 different attitudes. The first example shows a domestic design, warm colors, natural materials such as wood, furniture with classic trends. The second example offers a completely white space which, although it has indisputable architectural qualities, it is not in line with the needs of an elderly user with neurocognitive disorders, institutional 
neurocognitive, aspect de instituție și nu de locuință, nu sunt folosite contrastele, mobilier insuficient, lipsă de intimitate. Se recomandă încurajarea personalizării spațiului de către rezidenți împreună cu aparţinătorii şi îngrijitorii în spiritului unui Design Participativ 5 (Schuler, 2017; Bossen, 2016; Simonsen, 2013). Astfel, camera trebuie proiectată cu un design deschis, flexibil care să permită evoluții, completări cu obiecte de design familiare, fotografii.

Exteriorul unui astfel de centru ar trebui să aibă la fel un aspect cald, de cămin, să fie în concordanță și cu background-ul socio-cultural al persoanei vârstnice.

\section{Oferirea de oportunități de a interacționa dar și de a fi singur}

Un atu important pentru confortul persoanei vârstnice cu tulburări neurocognitive este menținerea unui balans optim între oportunitățile de a interacționa, a fi împreună cu ceilalți și de a petrece timp în intimitate. Persoana vârstnică trebuie să aibă posibilitatea de a alege cum vrea să își petreacă timpul desigur, încurajându-l să socializeze. Din punctul de vedere al arhitecturii, dacă vorbim despre vârstnicul instituționalizat sunt necesare spații variate, atât la interior cât și la exterior, cu caractere diferite care să ofere posibilitatea atât a discuțiilor retrase, cu 2-3 persoane, a activităților de grup extins dar și de a sta singur și de a citi sau contempla, uitându-te pe fereastră. Traduse în schema funcțională a unui centru de vârstnici, zona de zi poate include un living de socializare amenajat cu fotolii, canapele, mese pentru diferite activități ${ }^{6}$, separeuri pentru discuții mai intime și "camere liniștite" cu un design simplu și contact vizual direct cu natura (Níall McLaughlin appearance and not housing, contrasts are not used, insufficient furniture, lack of privacy. It is recommended to encourage the personalization of the space by residents together with their owners and caregivers in the spirit of Participatory Design ${ }^{5}$ (Schuler, 2017; Bossen, 2016; Simonsen, 2013). Thus, the room must be designed with an open, flexible design that allows evolutions, additions with familiar design objects, photographs.

The exterior of such a center should also have a warm, homey appearance, in line with the sociocultural background of the older person.

\section{Provide opportunities to be alone or with others}

An important asset in the comfort of the older person with neurocognitive disorders is maintaining an optimal balance between opportunities to interact, to be with others and spend time in privacy. The elderly person must be able to choose how he wants to spend his time, of course, encouraging him to socialize. From the point of view of architecture, if we talk about the institutionalized elderly, various spaces are needed, both indoor and outdoor, with different characters that offer the possibility of both withdrawn discussions, with 2-3 people, of extended group activities but also to sit alone and read or contemplate, looking out the window. Translated into the functional scheme of a seniors center, the living area can include a social living room with armchairs, sofas, tables for various activities ${ }^{6}$, compartments for more intimate discussions and "quiet rooms" with a simple design and direct visual contact with nature (Níall McLaughlin Architects, n.d. c). The courtyards of these centers can be 
Architects, n.d. c). Curțile acestor centre pot fi amenajate pe principiile grădinilor terapeutice dementia-friendly, cu zone diferite care activează un traseu în buclă, caracteristic: grădinărit, activități fizice, hrănit păsări, pictură, ascultat muzică, contemplate natura (Sym Studio, n.d.).

În contextul pandemiei actuale cu COVID-19 şi în vederea posibilităţii apariţiei de provocări similare pe viitor, este necesar să se asigure un mediu individual uşor de izolat şi de administrat dar care să nu creeze percepţia izolării, pe de o parte, şi crearea de circuite uşor gestionabile care să asigure flux unidirecţional al unui număr redus de persoane către şi dinspre spaţiile comune, izolarea spaţiilor destinate contactelor cu exteriorul (administrativ, zone de acces vizitatori) de spaţiile destinate vieţii rezidenţilor, eventual spații de cazare pentru personal (în vederea asigurării izolării acestora pentru lucrul pe ture de 14 zile), precum si spații tampon, dotate cu instalații de dezinfectare a aerului și a suprafețelor, și camere rezidențiale de rezervă, pentru a putea reloca rezidenții, prin rotație, în vederea desfășurării activităților de curățenie și dezinfecție în camerele acestora.

\section{Legătura cu comunitatea}

Așa cum spune și Fleming, reamintirea este esențială pentru păstrarea identității, "fără a-și reaminti constant cine este, o persoană care trăiește cu demență își pierde sentimentul identității" (Fleming R, 2020, p. 27).

Pentru persoanele vârstnice instituționalizate afectate de demență, separarea de familie, de comunitate reprezintă un factor de stres care poate contribui la calitatea scăzută a vieții, pierderea arranged on the principles of dementia-friendly therapeutic gardens, with different areas that activate a characteristic loop route: gardening, physical activities, feeding birds, painting, listening to music, contemplating nature (Sym Studio, n.d.).

In the context of the current pandemic with COVID19 and in view of the possibility of similar challenges in the future, it is necessary to ensure an individual environment that is easy to isolate and manage but does not create the perception of isolation, on the one hand, and the creation of circuits easily manageable to ensure a one-way flow of a small number of people to and from common areas, isolation of spaces intended for contacts with the outside (administrative, visitor access areas) from spaces intended for residents' lives, possibly accommodation for staff (in order to ensure isolation for working in 14-day shifts), as well as buffer spaces, equipped with air and surface disinfection facilities, and back up residential rooms, in order to be able to relocate residents, by rotation, in order to carry out cleaning and disinfection activities in their rooms.

\section{Link to the community}

As Fleming says, remembering is essential for the preservation of identity" without constant reminders of who they are, a person living with dementia loses their sense of identity" (Fleming R, 2020, p. 27).

For institutionalized elderly people affected by dementia, separation from family and community is a stressor that can contribute to low quality of life, loss of social identity and discrimination (Theurer, 
identității sociale și discriminare (Theurer, 2015). În vederea promovării incluziunii sociale și a participării persoanelor vârstnice cu afectare neurocognitivă, un centru dementia-friendly se recomandă să includă spații atât interioare cât și exterioare care să încurajeze vizitarea, interacțiunea cu familia, prietenii. Din acest punct de vedere, un centru de seniori este mai bine să fie plasat în oraș și nu retras, bine conectat la transport, ușor de accesat. Se recomandă de asemenea evitarea unei denumiri care să includă titlul de „special”, unitate specială pentru vârstnici cu demență tocmai pentru evitarea discriminării și stigmei (Link, 2001). Stigma asociată acestui diagnostic se naşte ca urmare a fricii, a lipsei de conştientizare si a lipsei de întelegere a bolii asociate acestui sindrom si poate genera multiple efecte negative precum: stimă de sine scăzută, izolare socială, scăderea calităţii vieţii etc. (Kim, 2019).

Din punctul de vedere al arhitecturii, pentru crearea unei punți cu orașul și comunitatea, pot fi introduse funcțiuni care pot atrage atât rezidenții cât și vizitatorii-familia, aparținătorii, prietenii precum o cafenea, cofetărie, restaurant (Sars, n.d.). De asemenea, pentru a încuraja familia să vină să își vadă părinții sau bunicii din centru se recomandă amenajarea unor zone de joacă pentru cei mici unde părinții își pot lăsa pentru scurt timp copiii.

\section{Design în concordanță cu viziunea asupra vieții}

Orice persoană în vârstă care urmează a se muta într-un centru care acordă asistentă vine cu un anumit bagaj socio-cultural care trebuie să fie
2015). In order to promote social inclusion and the participation of the elderly with neurocognitive disorders, a dementia-friendly center it is recommended to include both indoor and outdoor spaces to encourage visiting, interaction with family, friends. From this point of view, a senior center is better to be placed in the city and not secluded, well connected to transport, easy to access. It is also recommended to avoid a name that includes the title of "special", a special unit for the elderly with dementia ${ }^{7}$ precisely to avoid discrimination and stigma (Link, 2001). The stigma associated with this diagnosis arises from fear, lack of awareness and lack of understanding of the disease associated with this syndrome and can generate multiple negative effects such as low self-esteem, social isolation, decreased quality of life etc. (Kim, 2019).

From the point of view of architecture, for the creation of a bridge with the city and the community, functions can be introduced that can attract both residents and visitors-family, relatives, friends such as a cafe, confectionery, restaurant (Sars, n.d.). Also, in order to encourage the family to come to see their parents or grandparents in the center, it is recommended to arrange play areas for the little ones where the parents can leave their children for a short time.

\section{Design in response to vision for way of life}

Any older person who is to move to a care center comes with a certain socio-cultural background that must be respected. It is very important when the 
respectat. Este foarte important când familia alege un astfel de centru pentru cel drag să cunoască statutul acestuia, pe ce direcții se focusează, în acest sens centrele trebuie să își exprime clar pe canalele media de prezentare viziunea asupra acordării de asistență. Unele centre pun accent mai mult pe angrenarea în activități cotidiene de bază (ADL) și au de exemplu bucătării generoase, altele oferă servicii de lux sau pun accent pe recreere, altele pun accent pe un stil de viață sănătos și pe spiritualitate. Arhitectura și designul acestor centre ar trebui să exprime în mod sincer statutul de functionare al acestora (Níall McLaughlin Architects, n.d.).

\section{Posibilitățile pe care un mediu construit le oferă pentru activare}

În tulburările neurocognitive din spectrul bolii Alzheimer memoria este sever afectată alături de percepție şi funcţii executive. Aici putem vorbi despre spaţii cu rol de conținere pentru obiecte trigger de reminiscenţă, spaţii care prin formă şi design au funcţie de trigger precum şi despre spaţii pregătitoare, spaţii cu funcția de a invita și de a pregăti experienţa reamintirii. Vorbim de asemenea de spaţii de decompresie, care sa asigure trecerea naturală de la o experienţă terapeutică de tipul unei şedinţe de stimulare sau de reabilitare cognitivă la experienţa activităţilor vieţii zilnice în care se caută utilizarea beneficiilor intervenţiilor terapeutice (Ciobanu I, 2020).

Rutina învăţată privind funcţia spaţiului/spaţiilor parcurse este foarte importantă pentru că susţine family chooses such a center for the loved one to know its status, on which directions the center focuses, in this sense the centers must clearly express on the media channels the vision on providing assistance. Some centers place more emphasis on engaging in basic daily activities (ADL) and have, for example, generous kitchens, others offer luxury services or focus on recreation, others focus on a healthy lifestyle and spirituality. The architecture and design of these centers should sincerely express their operational status (Níall McLaughlin Architects, n.d.).

\section{Enabling opportunities provided by a} built environment

In neurocognitive disorders expressed in diseases like Alzheimer's, memory is severely disturbed, along with perception and executive functioning. Here we can talk about the importance of spaces containing objects with function of reminiscence triggers, spaces which through shape and design become triggers of reminiscence, as well as preparatory spaces, spaces inviting and preparing the inhabitant / user for the experience of reminiscing. We also talk here about decompression spaces, designed to provide the natural passage, from one therapeutic experience, like a session of cognitive stimulation or cognitive rehabilitation, to the experience of the activities of daily living, where we try to apply the gains we got from the therapeutic interventions (Ciobanu I, 2020).

The already learnt routine of the space, in terms of the functionality of the traveled space/spaces is very 
memoria remanentă, aceasta la rândul său va susţine simţul identităţii personale şi simţul coerenţei realităţii înconjurătoare şi al existenţei, ancorând persoana cu tulburări neurocognitive mai uşor în prezent şi în contextul spaţial şi al interacţiunilor cu echipa de îngrijire.

Spaţiile trebuie să permită iluminarea naturală şi artificială fără umbre şi spaţii ascunse care pot produce confuzie sau teamă. De asemenea, acustica spaţiilor trebuie atent gândită pentru a nu crea ventre în spaţii destinate interacţiunii şi noduri în zone de trecere, fără reverberaţii şi alte interferenţe.

Spaţiile trebuie gândite în ceea priveşte dimensionarea atât conform standardelor arhitecturale acceptate oficial pentru spaţiile cu destinaţie medicală dar și din punct de vedere etologic, respectând necesarul privind spaţiul personal şi spaţiul de acţiune al persoanelor cu TNC pentru a se evita orice senzaţie de apropiere excesivă, ce poate fi percepută ca o ameninţare. Spaţiul destinat interacţiunii trebuie gândit și din punctul de vedere al distanţelor interpersonale care să fie eficient din punct de vedere al distanţării în vederea reducerii răspândirii agenţilor patogeni cu transmitere pe cale respiratorie.

Spaţiile trebuie gândite din punctul de vedere al spaţiului de acţiune necesar pentru desfăşurarea diferitelor activităţi (îngrijire, igienă, activităţi sportive, recreative, lucrative) pentru persoane care, în afara de tulburări neurocognitive au dizabilităţi datorate diverselor afecţiuni neurologice si musculoscheletale, sindromului de fragilitate asociat vârstei. În acest sens trebuie luat în calcul şi deplasarea şi desfăşurarea activităţilor cu ajutorul important because it enables and supports the remaining memory, this, in its turn, supporting the sense of individual identity and the sense of coherence regarding the reality and one's existence itself, anchoring the person with neurocognitive disorders in the present and in the contextual space of his/her interactions with the care team.

Spaces must allow natural and artificial lighting, without shadows and hidden corners, which can induce confusion or fear. The space acoustic has to be also attentively thought of, in order not to create acoustic bellies in spaces designed for social interaction and acoustic nodes in passages, avoiding always echoes and sound interferences.

Spaces must be thought of also in regards with their sizing, to be in accord with the architectural standards, officially accepted for healthcare built spaces, but also thinking ethologically, respecting the requirements regarding personal space and action space for people with neurocognitive disorders, in order to avoid too close physical proximity, which can be perceived as threatening. The space for social interaction must also be designed in terms of interpersonal distances which should be effective in terms of distancing in order to reduce the spread of respiratory pathogens.

Also, spaces must be designed regarding the action space required for different defined activities (selfcare, hygiene, sports, leisure activities, hobbies and crafts) for people with neurocognitive disorders who present also disabilities associated to different neurological and musculoskeletal diseases or to frailty syndrome related to their age. Thus, we have to take into account also the space requirements related to moving and activity performing with the 
dispozitivelor asistive si cu ajutorul persoanelor care asigură îngrijirea plus ergonomia tuturor pieselor de mobilier prevăzute pentru persoane cu dizabilităţi.

Ca spații activatoare putem cataloga spațiile proiectate pentru a stimula memoria senzorială și pe cea procedurală, care vor antrena, la rândul lor, memoria episodică și reconectarea cu sine, cu istoria personală și cu prezentul. Aici putem include și spațiile care mimează domenii ale orașului și satului din tinerețe (Baxter, 2018; Kotecki, 2018; Keenan, 2014), mediile multisenzoriale (Snoezelen.2020; Cheng, 2019).

În aceeași categorie pot fi incluse spațiile destinate unei modalități complexe de reabilitare cognitivă și reconectare prin stimulare multisenzorială și terapie prin reminiscență emoțională, care fac obiectul unui proiect Active and Assisted Living aflat în desfășurare (Proiectul Sense-Garden. https://sense-garden.eu) și care este foarte bine primită de către beneficiari, persoane cu TNC și aparținători. Aceste sisteme permit personalizarea triggerelor de reamintire și a întregii experiențe, care include, alături de proiecții, sunet și interacțiunea cu propriile amintiri, și antrenament fizic, de memorie, funcții executive și de orientare spațio-temporală. Importantă, pentru reușita demersului terapeutic, este adaptarea conținutului și intensității experienței la nivelul de deficit cognitiv și la rezerva personală fizică, cognitivă și emoțională. Validarea eficienței acestui nou tip de intervenție este în curs de desfășurare. Proiectul Sense Garden propune un tip de spațiu care se pliază pe conceptul de MCAtn și care poate fi implementat în centre rezidențiale pentru vârstnici care acordă asistență de lungă durată. help of assistive devices and of persons providing care, as well as the need for space of the furniture and appliances designed for people with disabilities.

We can catalogue as enabling-spaces the spaces designed to stimulate the sensory memory as well as the procedural memory, which, at their turn, will train episodic memory and reconnection with self, with one's personal history and with the present time. Here we can include the spaces mimicking domains of the city or town of the youth (Baxter, 2018; Kotecki, 2018; Keenan, 2014) and sensory environments (Snoezelen, 2020; Cheng, 2019).

In the same class we can include spaces designed for a complex modality of cognitive rehabilitation and reconnection through multisensory stimulation and emotional reminiscence therapy, making the object of a recent Active and Assisted Living project (SenseGarden Project, https://sense-garden.eu). The intervention is very well received by the users people with neurocognitive disorders and their caregivers. These systems allow personalisation of reminiscence therapy triggers and of the whole experience which includes, along with projections, sound and interaction with one's memories, physical training, memory training, training of executive functions and space-time orientation training. For the success of the therapeutic approach is adapting the content and the intensity of the experience to the level of the cognitive deficit and to the physical, cognitive and emotional reserve. The validation procedure for this new kind of intervention is ongoing (Goodall-b, 2019). Sense Garden Project proposes a kind of space which folds on the concept of EBEnc and can be implemented in long term care residential centres. 


\section{Concluzii}

Conturarea unui Mediu Construit Activator Pentru Persoanele Vârstnice cu Tulburări Neurocognitive (MCAtn) este rezultatul unei munci de echipă, interdisciplinare. Un design pe principii dementiafriendly este un cumul atent gestionat care creează un echilibru optim de stimulare a persoanei vârstnice cu tulburări neurocognitive. Sunt importante toate aspectele, materiale, texturi, lumină naturală dar şi artificială generoase, obiecte decorative familiare, proporţii, scară domestică, culori activatoare/relaxante, detalii care ţin de siguranţă şi confort, spaţii comunitare generoase, atmosferă caldă, imagine exterioară prietenoasă, o bună conectare cu natura, integrare în contextul socio-cultural.

Arhitectura terapeutică dementia-friendly lucrează cu cele 5 instrumente avute la dispoziție: lumină, formă, culoare, textură, sunet care vin în sprijinul unei conduite terapeutice dedicate vârstnicilor cu TNC. Acestea pot fi utilizate atât separat cât şi sinergic. Conceptul MCAtn este esenţial în perspectiva în care calitatea vieţii persoanelor care trăiesc cu demenţă şi speranţa de viaţă sunt direct influenţate de nivelul de activare. Conceptul de MCAtn se sprijină pe alte principii deja existente precum implicare şi participare, un mediu centrat pe utilizator, pe OM, siguranţa, sănătatea şi starea de bine a utilizatorului, utilizarea potrivită a tehnologiei, orientare şi navigare, Design Universal. Conceptul de MCAtn îşi extrage esenţa din principiile unei Arhitecturi Prietenoase cu Vârsta dar care ia în considerare particularităţile date de tulburările neurocognitive, spre exemplu va ţine cont de

\section{Conclusions}

Shaping a Enabling Built Environment for Older Persons with Neurocognitive Disorders is the results of interdisciplinary team work. Building based on the principles of dementia-friendly design means creating optimal balance for stimulating the person with neurocognitive disorders using carefully managed cumulation of knowledge. All aspects regarding materials, textures, generous natural as well as artificial lighting, the presence of familiar decorative objects, sizing, domestic scaling, activating/relaxing colours, details regarding safety and comfort, generous community spaces, warm atmosphere, friendly exterior design, good connection with nature, a good integration into the social and cultural context.

Dementia-friendly therapeutic architecture works with the 5 tools we have at hand: light, shape, color, texture, sound, all coming to enable the therapeutic approach dedicated to elderly people with neurocognitive disorders. These tools can be used separately but also in synergic manner. The concept of EBEnc is essential in the perspective in which the quality of life of people living with neurocognitive disorders and their life hope are directly influenced by their level of activation. The concept of EBEnc is supported by other principles, already known, as involvement \& participation, user (human) centered environment, safety, user's health and wellbeing, appropriate use of technology, orientation \& navigation, Universal Design. The concept of EBEnc extracts its essence from the Principles of AgeFriendly Architecture but also takes into account the specific requirements of the people with 
ierarhia de percepere a caracteristicilor unui spaţiu, mai întâi forma, apoi culoarea şi în final funcţiunea.

Pornind de la conceptul MCAtn, arhitectura dementia-friendly este o arhitectură care asumă principiile arhitecturii prietenoase pentru vârstnici, dezvoltând în plus trăsături specifice, coroborate cu simptomele tulburărilor neurocognitive. Arhitectura dementia-friendly își propune să compenseze deficite, să maximizeze independența, să păstreze demnitatea, să orienteze, să consolideze identitatea personală, să fie primitoare și să permită controlul de stimuli. Un spaţiu activator pentru o persoană vârstnică cu tulburări neurocognitive oferă o stimulare multisenzorială.

Arhitectura dementia-friendly reprezintă o schimbare de paradigmă necesară pentru societatea contemporană. Conceptul de MCAtn trebuie să fie aplicat în primul rând la nivel de obiect de arhitectură, la nivel urban fiind mai dificil încă, rezumându-se mai mult la aspectele prietenoase cu vârsta. Operaționalizarea conceptului de MCAtn crește calitatea vieții persoanelor cu tulburări neurocognitive şi susţine starea de bine.

Mediul construit influențează calitatea vieții atât a persoanelor cu tulburări neurocognitive cât și a îngrijitorilor formali sau informali. Un mediu construit pe principiile MCAtn va contribui la menținerea indepedenței pentru cât mai mult timp a persoanelor cu tulburări neurocognitive, pentru că:

“Nu ai nevoie de o memorie nemaipomenită ca să te simți bine."

(Dementia Australia, 2014) neurocognitive disorders, for example will keep into account the hierarchy of perception regarding the features of a space: first - the shape, second - the color, third - the functionality.

Starting from the concept of EBEnc, dementiafriendly architecture is an architecture which assumes the principles of age-friendly architecture, developing further specific features, corroborated with the symptomatology of neurocognitive disorders. Dementia-friendly architecture aims to compensate deficits, to maximise independence, to foster dignity, to orient, to consolidate personal identity, to be welcoming and to allow control over stimuli. An activating (activator) space for an elderly person presenting with neurocognitive disorder provides the user with multisensory stimulation.

Dementia-friendly architecture means a change of paradigm required by the contemporaneous society. The concept of EBEnc must be applied first at the level of architectural object, at urban level being yet a bit difficult, being restricted to agefriendly aspects. Operationalisation of the concept of EBEnc improves the quality of life of people with neurocognitive disorders and enables wellbeing.

Built environment influences the quality of life of people with neurocognitive disorders as well as the persons providing care, formal and informal caregivers alike. An environment built in accord with the principles of EBEnc will contribute to maintaining independent life for people with neurocognitive disorders for longer, because:

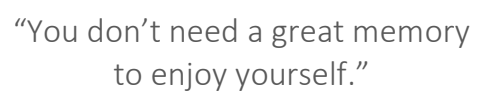

(Dementia Australia, 2014) 


\section{Referinţe/ References}

AAB DIE RAUMKULTUR GMBH. (n.d.) Zone Tehnologie de tip Ambient Assistive Living (AAL) [Fotografie]. https://www.homify.de/foto/506555/aal-ambient-assisted-living-barrierefreie-altersgerechte-wohnung

Adekoya, A.A. \& Guse, L. (2019). Wandering Behavior From the Perspectives of Older Adults With Mild to Moderate Dementia in Long-Term Care. Research in Gerontological Nursing. 12 (5): 239-247.

AlPRemodeling.com. (n.d.). Tile Roll-In Showers. Accesat în 2020.12.02 la https://www.aipremodeling.com/accessibleshowers/roll-in-shower/

Alzheimer's Disease International. (n.d.) Alzheimer's Disease International Virtual International Conference. 10-12 December 2020. Accesat în 16.10.2020 la https://adi2020.org.

Alzheimer's Society. (n.d.). Exercise in the early to middle stages of dementia. Accesat în 16.10 .2020 la https://www.alzheimers.org.uk/get-support/daily-living/exercise/early-middle-dementia

archdaily.com. (n.d.). Căminul de seniori Hainburg / Christian Kronaus + KNOWSPACE [Fotografie]. https://www.archdaily.com/61115/hainburg-nursing-home-christian-kronaus-erhard-an-hekinzelbach/5009129f28ba0d27a700163d-hainburg-nursing-home-christian-kronaus-erhard-an-he-kinzelbachphoto

Baxter, A. (2018). Senior Helpers to Staff First U.S. Dementia Village. Accesat la https://homehealthcarenews.com/2018/03/senior-helpers-to-staff-first-u-s-dementia-village/

Bossen, C. (Ed). (2016). PDC 2016, Participatory design in an era of participation: proceedings of the 14th Participatory Design Conference : August 15-19, 2016, Aarhus, Denmark. Association for Computing Machinery. https://doi.org/10.1145/2940299.

Brawley, E.C. (1997). Designing for Alzheimer's Disease Strategies for Creating Better Care Environments. New Jersey: John Wiley \& Sons.

Bridges. (n.d.). Understanding and Managing Challenging Dementia Behaviors. Accesat la 16.10.2020: https://www.bridgesbyepoch.com/resources/educational-resources/understanding-and-managing-challengingdementia-behaviors-1539705791

Calkins, M.P. (1988). Design for dementia: planning environments for the elderly and the confused. Maryland: National Health Publishing.

Chan, K.Y., Adeloye, D., Campbell, H., et al. (2019). Tackling dementia globally: The Global Dementia Prevention Program (GloDePP) collaboration. Journal of Global Health. 9 (2).

Cheng, C., Baker, G.B., Dursun, S.M. (2019). Use of multisensory stimulation interventions in the treatment of major neurocognitive disorders. Psychiatry and Clinical Psychopharmacology. 29 (4): 916-921.

Ciobanu, I., Zamfir, M., Marin, A.G. et al. (2020). Spaţiul terapeutic în reabilitarea medicală, coordonate contemporane. În: A, Bighea (Ed). Reabilitarea medicală. Actualităţi 2020. Ed. MEDICHUB MEDIA. Bucureşti. pp.52-56.

Cohen, U., Weisman, G.D. (1991). Holding on to home: designing environments for people with dementia. Baltimore: Johns Hopkins University Press. 
Comisia Europeană. (n.d.). Urbanizarea ]n Europa. Accesat în 16.10.2020 la

https://ec.europa.eu/knowledge4policy/foresight/topic/continuing-urbanisation/urbanisation-europe_en.

Day, K., Carreon, D., Stump, C. (2000). The therapeutic design of environments for people with dementia: a review of the empirical research. The Gerontologist. 40 (4): 397-416.

Dementia Australia. Dementia - activities and exercise. 2014, https://www.betterhealth.vic.gov.au/health/ConditionsAndTreatments/dementia-activities-and-exercise

Dietger Wissonig Architekten. (n.d.) Amenajare unitate de cazare-Centrul de Seniori Graz, 2010, Portugalia [Fotografie]. https://divisare.com/projects/328414-dietger-wissounig-architekten-peter-rosegger-nursing-home

Elderly Accommodation Counsel. (2020). Ellesmere Care Home, Chelsea, London [Photo]. https://housingcare.org/downloads/facilities/photos/158505_5.jpg

Fernando Guerra | FG + SG. (n.d.) Căminul Alcacer do Sal / Aires Mateus [Fotografie]. https://www.archdaily.com/328516/alcacer-do-sal-residences-aires-mateus/51116fa5b3fc4b75d900005c-alcacerdo-sal-residences-aires-mateus-photo?next_project=no

Fiatarone, M.A. (1990). High-intensity strength training in nonagenarians. Effects on skeletal muscle. JAMA: The Journal of the American Medical Association. 263 (22): 3029-3034.

Fleming, R., Zeisel, J., Bennet, K. (2020). World Alzheimer Report 2020: Design, Dignity, Dementia: Dementia-related design and the built environment. Volume 1, London, England: Alzheimer Disease International. https://www.alz.co.uk/u/WorldAlzheimerReport2020Vol1.pdf

Hyde, J. (1989). The physical environment and the care of Alzheimer's patients: An experiential survey of Massachusetts' Alzheimer's units. American Journal of Alzheimer's Disease and Other Dementias. 4(3):36-44.

Jesper, S., Robertson, T. (2013). Routledge international handbook of participatory design. New York: Routledge.

Judd, S., Marshall, M., Phippen, P. (1998). Desig nfor Dementia. London: Hawker.

Kambič, M. (n.d.) Centrul pentru Seniori Hodoš, 2010, Ravnikar Potokar Arhitekturni, Hodoš, Slovenia [Fotografie]. https://www.archdaily.com/128347/the-hodos-centre-for-the-elderly-ravnikar-potokararhitekturni/50140c5428ba0d3b45000e02-the-hodos-centre-for-the-elderly-ravnikar-potokar-arhitekturniphoto?next_project=no

Kane, N \& Karatzas, J. (n.d.) Centru Respiro Alzheimer, 2009, Niall McLaughlin Architects, Dublin, Irlanda [Fotografie] http://acdn.architizer.com/thumbnails-PRODUCTION/ad/ea/adea5fc8b1141196d452b393cf6c9860.jpg

Keenan, H. (2014). People living with dementia and the built environment. Australian Journal of Dementia Care. https://journalofdementiacare.com/people-living-with-dementia-and-the-built-environment/

Kim S., Kim S., Werner P., et al. (2019). Dementia Stigma Reduction (DESeRvE): Study protocol for a randomized controlled trial of an online intervention program to reduce dementia-related public stigma. Contemporary Clinical Trials Communications Jun; 14: 100351.

Kotecki, P. (2018). Fake 1950s-era towns are popping up across the US to help dementia patients - take a look. Accesat la https://www.businessinsider.com/alzheimer-memory-towns-dementia-patient-cognition-2018-10 
Kunduraci, A.C. (2017). LIGHTING DESIGN FOR THE AGING EYES. MATTER: International Journal of Science and Technology. 3 (3): 185-194.

Lawton, M.P., Kleban, M.H., Fulcomber, M. (1984) Architecture for the mentally impaired elderly. Environment \& Behavior. 16(6):730.

Link, B.G., \& Phelan, J.C. (2001). Conceptualizing Stigma. ANNUAL REVIEW OF SOCIOLOGY. 27: 363-385.

Marquardt, G. (2011). Wayfinding for people with dementia: A review of the role of architectural design. Health Environments Research and Design Journal. 4 (2): 75-90.

McManus, D. (2020.08.24). Ellesmere Nursing Home London, Fulham Road Property, Chelsea Building Project [Fotografie]. https://www.e-architect.com/images/jpgs/london/ellesemere_nursing_home_071110_2.jpg

modlar.com. (n.d.) Centru de Seniori în Esternberg, 2008, Arhitecți Gärtner+Neururer, Esternberg, Austria [Fotografie]. https://www.modlar.com/photos/8181/nursing-home-in-esternberg-exterior/

National Institute on Aging. (n.d.). Aging in Place: Growing Older at Home. Accesat în 16.10.2020 la https://www.nia.nih.gov/health/aging-place-growing-older-home.

Níall McLaughlin Architects. (n.d. a). Alzheimer's Respite Centre, Dublin [Fotografie]. http://www.niallmclaughlin.com/wp-content/uploads/2012/07/0110_Alzheimers-NK_S_18-387x490.jpg

Níall McLaughlin Architects. (n.d. b). Alzheimer's Respite Centre, Dublin [Fotografie]. http://www.niallmclaughlin.com/wp-content/uploads/2012/07/0110_Alzheimers-JK_S_02-676x449.jpg

Níall McLaughlin Architects. (n.d. c). Alzheimer's Respite Centre, Dublin [Fotografie]. http://www.niallmclaughlin.com/wp-content/uploads/2012/07/0110_Alzheimers-NK_S_16-600x490.jpg

Níall McLaughlin Architects. (n.d. d) Arhitectură dementia-friendly-Centru Respiro Alzheimer, 2009 [Fotografie]. http://www.niallmclaughlin.com/wp-content/uploads/2012/07/0110_Alzheimers-NK_S_04-676x361.jpg

Nuzum, H., Stickel, A., Corona, M, et al. 2020. Potential Benefits of Physical Activity in $\mathrm{MCl}$ and Dementia. Behavioural Neurology. 2020: 7807856

Oliveira, A.M.D., Radanovic, M., Mello, P.C.H.D. et al. (2015). Nonpharmacological interventions to reduce behavioral and psychological symptoms of dementia: A systematic review. BioMed Research International. 2015:218980. doi: $10.1155 / 2015 / 218980$

Ocaña, M. (n.d. a). Centrul Geriatric Santa Rita, Menorca, Spania [Fotografie]. https://www.archdaily.com/941691/housing-for-the-elderly-examples-of-independence-and-communityliving/5ee77aadb35765473e000067-housing-for-the-elderly-examples-of-independence-and-community-livingimage

Ocaña, M. (n.d. b). Centrul Geriatric Santa Rita, Menorca, Spania [Fotografie]. https://www.archdaily.com/24725/santa-rita-geriatric-center-manuel-ocana/5010489a28ba0d4222001642-santarita-geriatric-center-manuel-ocana-image?next_project=no

Ocaña, M. (n.d. c). Centrul Geriatric Santa Rita, Menorca, Spania [Fotografie]. https://www.archdaily.com/24725/santarita-geriatric-center-manuel-ocana/501048c328ba0d422200164a-santa-rita-geriatric-center-manuel-ocanaimage?next_project=no 
Ott, P. (n.d. a). Centrul Rezidențial Andritz / Dietger Wissounig Architekten [Fotografie]. https://www.archdaily.com/787044/residential-care-home-andritz-dietger-wissounigarchitekten/572f8a63e58ece4d83000046-residential-care-home-andritz-dietger-wissounig-architekten-photo

Ott, P. (n.d. b). Căminul de seniori Hainburg / Christian Kronaus + KNOWSPACE [Fotografie]. https://www.archdaily.com/61115/hainburg-nursing-home-christian-kronaus-erhard-an-hekinzelbach/5009129f28ba0d27a700163d-hainburg-nursing-home-christian-kronaus-erhard-an-he-kinzelbachphoto

Patterson, W. (n.d.) D'Youville Center for Advanced Therapy, SUA [Fotografie]. https://i.pinimg.com/736x/7a/6e/eb/7a6eeb67dff3c2bbaa853ff31adeac25.jpg

Preiser, W.F.E., Ostroff, E. (2001). Universal design handbook. New York: McGraw-Hill.

Sars, M. (n.d.) Spații de interacțiune-Cartierul Dementia De Hogeweyk, 2010, DWA Architects, Olanda [Fotografie]. https://aej.com.au/wp-content/uploads/2015/05/De-Hogeweyk-01-2000x1150.jpg

Schiff, M.R. (1990). Designing environments for individuals with Alzheimer's disease: Some general principles. American Journal of Alzheimer's Disease and Other Dementias. 5(3):4-8.

Schuler, D. (2017). Participatory Design. London: CRC Press. https://www.taylorfrancis.com/books/e/9780203744338

Silverstein, N.M., Flaherty, G., Tobin, T.S. (2006). Dementia and wandering behavior: concern for the lost elder. New York: Springer Pub. Co.

Skelton, D.A., Mavroeidi , A. (2018). How do muscle and bone strengthening and balance activities (MBSBA) vary across the life course, and are there particular ages where MBSBA are most important? Journal of Frailty, Sarcopenia and Falls. 3 (2): 74-84.

Snoezelen. (2020). Snoezelen for the elderly. Accesat la https://www.snoezelen.info/who-can-benefit/snoezelen-forthe-elderly/

studiolada. (n.d.) Extinderea Căminului Vaucauleurs, Franța [Fotografie]. http://www.studiolada.fr/files/gimgs/220_01.jpg

Sym Studio. (n.d.) Grădina terapeutică multisezorială, Carl Gilmore Landscapes, North Ryde, Australia [Fotografie]. https://i.pinimg.com/564x/09/07/db/0907dbe7a979ae0ddd8b488f6566fa12.jpg

Theurer, K., Mortenson, W.B., Stone, R. et al. (2015). The need for a social revolution in residential care. Journal of Aging Studies. 35: 201-210.

Toots, A., Littbrand, H., Lindelöf, N. et al. (2016). Effects of a High-Intensity Functional Exercise Program on Dependence in Activities of Daily Living and Balance in Older Adults with Dementia. Journal of The American Geriatrics Society. 64(1):55-64.

Trivedi D.P., Braun, A., Dickinson, A. et al. (2019). Managing behavioural and psychological symptoms in community dwelling older people with dementia: 1 . A systematic review of the effectiveness of interventions. Dementia (London, England). 18 (7-8).

United Nations. (2020, Mai 8). COVID-19 and Older Persons: A Defining Moment for an Informed, Inclusive and Targeted Response. Accesat la https://www.un.org/development/desa/ageing/news/2020/05/covid19/. 
United Nations. (n.d.) Ageing. Accesat în 16.10.2020 la https://www.un.org/en/sections/issues-depth/ageing/.

United Nations Population Division. (2019). World Population Prospects: the 2019 Revision. Accesat la https://population.un.org/wpp/.

World Health Organization. (2007). Global Age-friendly Cities: A guide. Geneva, Switzerland: WHO Press.

World Health Organization. (2018). Ageing and health. Accesat la https://www.who.int/news-room/factsheets/detail/ageing-and-health

Zamfir, M., Moglan, M., Bogdan, D.C. et al. (2020). Future cities' architecture, architecture for active and healthy ageing. Smart Cities and Regional Development Journal. 4(2):103-116.

\begin{abstract}
${ }^{1}$ Arhitecta din echipă, Mihaela Zamfir, în cadrul tezei de doctorat - Spre o arhitectură a comunității. Repere interdisciplinare pentru societatea contemporană urbană (2014) introduce această perspectivă a vârstei în arhitectură într-un capitol dedicat./ The team architect, Mihaela Zamfir, in her PhD thesis-Towards a community architecture. Interdisciplinary highlights for contemporary urban society (2014) introduces this perspective of age in architecture in a dedicated chapter.

${ }^{2}$ Detalii despre proiect/More details about this project: https://www.aal-europe.eu/projects/sensegarden/

${ }^{3}$ Richard Fleming este prof. univ. la Facultatea de Științe, Medicină și Sănătate, Universitatea Wollongong, Australia, psiholog clinician, doctor în științe, cu o vastă experiență în îngrijirea persoanelor vârstnice./
\end{abstract}

Richard Fleming is a university professor at the Faculty of Science, Medicine and Health, Wollongong University, Australia, clinical psychologist, PhD, with extensive experience in caring for the elderly.

${ }^{4}$ Dromomania este un simptom comportamental frecvent întâlnit la persoanele cu demență, unul dintre cele mai provocatoare şi dificile de gestionat. Dromomania se referă la tendința marcată de a pleca de acasă sau de a părăsi locuri familiare pentru persoana afectată de demență. Dromomania constă în incapacitatea persoanei vârstnice cu TNC de a-şi găsi drumul corect în atingerea unui scop sau pentru satisfacerea unei nevoi./

Wandering is a common behavioral symptom in people with dementia, one of the most challenging and difficult to manage. Wandering refers to the marked tendency to leave home or leave familiar places for the person affected by dementia. Dromomania is the inability of the older person with NCD to find the right path to achieve a goal or to meet a need.

${ }^{5}$ Designul Participativ numit iniţial Design Cooperativ implică toate părţile interesate, designeri, cercetători şi utilizatori finali în scopul asigurării ca produsul final să întâmpine aşteptările tuturor. Designul participativ este considerat atât un proces cât şi o strategie care implică clienţii şi utilizatorii finali în procesul de creaţie./

Participatory Design originally called Cooperative Design involves all stakeholders, designers, researchers and end users in order to ensure that the final product meets everyone's expectations. Participatory Design is considered both a process and a strategy that involves customers and end users in the creative process.

${ }^{6}$ Activităţile cu persoanele vârstnice instituţionalizate au scopul de a stimula capacitatea participativă şi interacţiunea la nivel de grup, aducând astfel beneficii atât asupra statusului cognitiv cât şi asupra calităţii vieţii acestora. Aceste activităţi pot fi realizate indivudual sau în grup astfel: 
(1) individual prin intermediul unor fişe de lucru sau caiete de activităţi, aplicaţii computerizate ce au rolul de a stimula capacitatea de atenţie, concentrare, memorie şi calcul mental, viteza de reacţie; acestea necesită un spaţiu retras, intim, liniştit şi bine luminat.

(2) diverse activităţi şi sarcini complexe de terapie ocupaţională ce pot fi realizate individual sau în grup/echipă-grădinărit, gospodărie, pictură, sculptură, modelaj, etc.; acestea sunt de preferat a se desfăşura în spaţiile comune unde aceştia pot interacţiona în mod direct./

Activities with institutionalized older people aim to stimulate participatory capacity and group-level interaction, thus bringing benefits to both their cognitive status and their quality of life. These activities can be done individually or in groups as follows:

(1) individually through worksheets or activity books, computer applications that have the role of stimulating the ability of attention, concentration, memory and mental calculation, reaction speed; they require a secluded, intimate, quiet and welllit space.

(2) various activities and complex occupational therapy tasks that can be performed individually or in a group / teamgardening, household, painting, sculpture, modeling, etc .; they are preferable to take place in common areas where they can interact directly.

${ }^{7}$ Termenul de demenţă adesea poate duce la etichetare, discriminare, separarea şi chiar pierderea statutului în societate și a rolului în familie./

The term dementia can often lead to labeling, discrimination, separation and even loss of status in society and role in the family. 